Jurnal Akuntansi Manajemen Madani

Vol. 7, No. 1, Maret 2021

\title{
ANALISIS PERHITUNGAN HPP BERDASARKAN METODE FULL COSTING \\ DAN VARIABLE COSTING SEBAGAI DASAR DALAM MENENTUKAN HARGA \\ JUAL PADA UKM. UD. MUTIARA FURNITUR BALIKPAPAN
}

\author{
Fauziah Yuspyani \\ Adi Prihanisetyo
}

\author{
STIE Madani, Balikpapan \\ Email: \\ fyuspyani@gmail.com \\ adi@stiemadani.ac.id
}

\begin{abstract}
ABSTRAK
Penelitian ini bertujuan untuk mengetahui perhitungan HPP HPP menurut perusahaan, untuk mengetahui perhitungan HPP apabila menggunakan metode yang baku, dan untuk mengetahui perbandingan dari kedua metode tersebut serta pengaruhnya terhadap harga jual. Teknik pengumpulan data yang digunakan dalam penelitian ini adalah observasi, wawancara, dan dokumentasi. Penelitian ini termasuk penelitian kuantitatif, data yang digunakan, data primer. Hasil dari penelitian ini menunjukkan adanya kelemahan dalam perhitungan HPP perusahaan. Berdasarkan perbandingan metode full costing dan variable costing dalam perhitungan HPP perusahaan, metode perusahaan menghasilkan nilai nominal lebih rendah dibandingkan metode full costing dan variable costing. Penelitian ini menyimpulkan bahwa perhitungan HPP yang dilakukan perusahaan kurang tepat.
\end{abstract}

Kata Kunci : HPP, Metode Full Costing, Metode Variable Costing, dan Harga Jual.

\section{PENDAHULUAN}

Kemajuan dunia usaha saat ini jauh berkembang dengan pesat, baik dalam skala kecil maupun skala besar, serta perkembangan di sektor industri yang memiliki peran penting dalam sektor perekonomian di dunia. Kegiatan produksi memerlukan berbagai pengorbanan jenis biaya untuk menghasilkan produk yang akan dipasarkan. Biaya-biaya ini akan menjadi dasar dalam penentuan HPP. Menurut Siregar (2014:28) HPP adalah biaya yang terjadi untuk mengubah bahan baku menjadi barang jadi. Setiap konsumen menginginkan produk yang sesuai dengan kebutuhan dan selera yang diinginkan konsumen dengan kualitas yang baik dan harga jual yang terjangkau. 
Dalam menentukan harga jual maka diperlukan penentuan HPP yang sesungguhnya yaitu merupakan salah satu pembahasan teori yang ada di dalam akuntansi biaya. Dengan demikian, sebuah UKM perlu mengetahui bagaimana cara penyusunan dan perhitungan HPP yang tepat. Tujuan laporan keuangan adalah menyediakan informasi posisi keuangan dan kinerja suatu entitas yang bermanfaat bagi sejumlah besar pengguna dalam pengambilan keputusan ekonomi bagi pengguna tersebut seperti pemilik perusahaan.

Sistem perhitungan HPP suatu produk dipengaruhi oleh biaya-biaya produk yang digunakan. Salah satu penentuan harga jual dengan cara menentukan terlebih dahulu jumlah HPP yang sebenarnya dengan menggunakan metode full costing dan variable costing. Full costing menurut Mulyadi (2014:17) merupakan biaya produksi yang memperhitungkan semua unsur biaya produksi ke dalam biaya produksi, yang terdiri dari biaya bahan baku, biaya tenaga kerja langsung dan biaya overhead pabrik yang berperilaku tetap maupun variabel. Variable costing menurut Mulyadi (2014:17) metode penetuan HPP yang membebankan biaya produksi yang berperilaku variabel ke dalam keadaan HPP, yang terdiri dari biaya bahan baku, biaya tenaga kerja langsung dan biaya overhead pabrik variabel.

Usaha Kecil Menengah (UKM) adalah usaha yang memiliki kekayaan bersih lebih dari Rp 50.000.000 dan kurang dari Rp 300.000.000 tidak termasuk tanah dan bangunan, sesuai dengan kriteria dan cirri-ciri UKM pada Undang-Undang No. 20 Tahun 2008 tentang Usaha Mikro, Kecil dan Menengah. UKM merupakan suatu bentuk usaha kecil masyarakat yang pendiriannya berdasarkan inisiatif seseorang.

UD. Mutiara Furnitur Balikpapan adalah suatu usaha industri manufaktur skala kecil yang bergerak dalam kegiatan usaha produksi meubel furnitur yang menghasilkan produk sofa. Dalam perhitungan HPPnya masih sangat sederhana serta tidak memasukan keseluruhan biaya overhead pabrik dalam perhitungan HPPnya.

Hal ini menimbulkan permasalahan karena produk yang dihasilkan tidak mencerminkan biaya secara keseluruhan. Usaha ini merupakan kasus penggunaan metode perhitungan HPP yang masih sangat minim. Kehadiran metode full costing dan variable costing membuat manajemen mampu memperbaiki penelusuran biaya yang berperilaku variabel maupun tetap. Berdasarkan latar belakang yang telah diuraikan diatas, permasalahan yang akan dibahas dalam penelitian ini, dirumuskan sebagai berikut: Bagaimana perhitungan HPP sofa pada UD. Mutiara Furnitur 
Balikpapan ?, Bagaimana perhitungan HPP sofa berdasarkan metode full costing dan variable costing ?, Bagaimana perbandingan perhitungan HPP sofa antara metode full costing dan variable costing dengan metode perhitungan HPP perusahaan untuk menentukan harga jual ?

\section{KERANGKA TEORI}

\section{A. Definisi Dan Penggolongan UKM}

UKM (Usaha Kecil Menengah) berperan dalam mendorong laju pertumbuhan ekonomi.

UKM mempunyai peran yang strategis dalam pembangunan dan perkembangan perekonomian. Usaha kecil menengah merupakan suatu usaha kecil masyarakat yang pendiriannya berdasarkan inisiatif seseorang. Menurut UU No. 20 Tahun 2008 Pasal 6 mengenai UMKM menjelaskan bahwa Usaha Mikro (UM) adalah entitas usaha yang mempunyai memiliki kekayaan bersih paling banyak Rp 50.000.000 tidak termasuk tanah dan bangunan tempat usaha atau memiliki hasil penjualan tahunan paling banyak Rp 300.000.000. Usaha Kecil (UK) adalah entitas usaha yang mempunyai memiliki kekayaan bersih lebih dari Rp 50.000.000 sampai dengan paling banyak Rp 500.000.000 tidak termasuk tanah dan bangunan tempat usaha atau memiliki hasil penjualan tahunan lebih dari Rp 300.000.000. Sementara itu, Usaha Menengah adalah entitas usaha yang mempunyai memiliki kekayaan bersih lebih dari Rp 500.000.000 dan paling banyak Rp 10.000.000.000 tidak termasuk tanah dan bangunan tempat usaha atau memiliki hasil penjualan tahunan lebih dari $\mathrm{Rp}$ 2.500.000.000.

\section{B. Definisi Akuntansi Biaya}

Menurut Supriyono (2013:12) pengertian akuntansi biaya adalah suatu cabang akuntansi yang merupakan alat manajemen dalam monitor dan merekam transaksi biaya secara sistematis, serta menyajikan informasi biaya dalam bentuk laporan biaya. Dari definisi di atas dapat ditarik kesimpulan bahwa akuntansi biaya merupakan salah satu cabang dari akuntansi yang membantu manajemen dalam pengawasan biaya produksi untuk menentukan harga jual dan mendapatkan laba. 


\section{HPP}

Menurut Mulyadi (2014:16) HPP adalah total biaya-biaya yang terjadi untuk mengolah bahan baku menjadi produk yang siap untuk dijual. Menurut Mulyadi (2014:65) manfaat HPP dalam perusahaan bagi manajemen untuk, menentukan harga jual produk, memantau realisasi biaya produksi, menghitung laba atau rugi periodik, menentukan harga pokok persediaan produk jadi dan produk dalam proses yang disajikan dalam neraca. Dari definisi di atas dapat ditarik kesimpulan bahwa pengertian dari HPP merupakan keseluruhan dari biaya-biaya yang terdiri dari biaya bahan baku, biaya tenaga kerja langsung dan biaya overhead pabrik yang dikorbankan dalam proses produksi sehingga menjadi barang jadi yang siap untuk dijual untuk memperoleh penghasilan.

\section{Komponen HPP}

1. Biaya bahan baku

Menurut Supriyono (2013:20) adalah barang yang dikonsumsi perusahaan yang dapat digolongkan ke dalam bahan dan barang yang bukan bahan.

2. Biaya tenaga kerja

Menurut Supriyono (2013:20) biaya tenaga kerja adalah semua balas jasa yang akan diberikan perusahaan kepada semua karyawan.

\section{Biaya overhead pabrik}

Menurut Sujarweni (2015:54) adalah semua biaya produksi selain biaya bahan baku langsung dan biaya tenaga kerja langsung.

\section{E. Metode Perhitungan HPP}

Dalam memperhitungkan unsur-unsur biaya ke dalam HPP, terdapat dua pendekatan yaitu full costing dan variable costing. Menurut Mulyadi (2014:17) Full costing adalah metode penentuan HPP yang membebankan seluruh biaya produksi terdiri dari biaya bahan baku, biaya tenaga kerja langsung, biaya overhead pabrik, baik yang berperilaku tetap maupun variabel di tambah biaya non produksi (biaya pemasaran dan administrasi \& umum). Penentuan HPP berdasarkan full costing pada umumnya ditujukan untuk kepentingan penyusunan laporan keuangan untuk pihak eksternal. Dari pengertian di atas dapat ditarik kesimpulan bahwa unsur harga pokok produk menurut metode ini meliputi: 


\begin{tabular}{|c|c|}
\hline Biaya bahan baku & $\operatorname{Rp} x x x$ \\
\hline Biaya tenaga kerja langsung & $\operatorname{Rp} x x x$ \\
\hline Biaya overhead pabrik tetap & Rp. $x x x$ \\
\hline Biaya overhead pabrik variabel & $\underline{\text { Rp. } x x x+}$ \\
\hline Rp. $x x x$ & \\
\hline
\end{tabular}

Menurut Mulyadi (2014:18) Variable costing adalah metode penentuan HPP yang hanya memperhitungkan biaya produksi biaya produksi yang berperilaku variabel ke dalam HPP, yang terdiri dari biaya bahan baku, biaya tenaga kerja langsung, dan biaya overhead pabrik variabel. Penentuan HPP berdasarkan metode ini pada umumnya ditujukan untuk pihak manajemen dalam rangka pengambilan kebijakan harga. Dari pengertian di atas dapat ditarik kesimpulan bahwa unsur harga pokok produk menurut metode ini meliputi:

$\begin{array}{ll}\text { Biaya bahan baku } & \mathrm{Rp} x \mathrm{xx} \\ \text { Biaya tenaga kerja langsung } & \mathrm{Rp} \mathrm{xxx} \\ \text { Biaya } \text { overhead pabrik variabel } & \underline{\mathrm{Rp} x x x+} \\ \text { HPP } & \mathrm{Rp} \mathrm{xxx}\end{array}$

\section{F. Harga Jual}

Supriyono (2013:211) menyatakan bahwa harga jual adalah jumlah moneter yang dibebankan oleh suatu unit usaha kepada pembeli atau pelanggan atas barang atau jasa yang dijual atau diserahkan. Dari pengertian di atas dapat ditarik kesimpulan bahwa harga jual merupakan jumlah moneter yang dibebankan oleh suatu unit usaha kepada pembeli atas barang atau jasa yang dijual atau diserahkan yang terdiri dari biaya produksi, biaya pemasaran, dan biaya administrasi dan umum ditambah dengan tingkat keuntungan (margin) yang diinginkan oleh UKM.

\section{G. Metode Penetapan Harga Jual (cost plus pricing)}

Menurut Sujarweni (2015:75) Metode penentuan harga jual berdasarkan biaya dalam bentuk yang paling sederhana yaitu cost plus pricing method. Penentuan harga jual cost plus pricing adalah biaya yang digunakan sebagai dasar penentuan harga pokok produk yang digunakan. Menurut sujarweni menyatakan bahwa pada prinsipnya harga jual harus dapat menutupi biaya penuh ditambah dengan laba yang wajar. Harga jual sama dengan biaya produksi 
ditambah margin. Dalam metode ini, penjual atau produsen menetapkan harga untuk satu unit barang yang besarnya sama dengan jumlah biaya perunit, ditambah dengan suatu jumlah laba yang diinginkan.

\section{H. Metode Penyusutan Aktiva Tetap}

Menurut Standar Akuntansi Keuangan untuk Entitas Mikro, Kecil, Dan Menengah (SAK EMKM) oleh Ikatan Akuntan Indonesia (2018:26) menyatakan bahwa perhitungan penyusutan aktiva tetap dapat dilakukan dengan menggunakan metode garis lurus tanpa memperhitungkan nilai residu (nilai sisa).

\section{METODOLOGI PENELITIAN}

\section{A. Jenis Penelitian}

Jenis penelitian dalam penelitian ini adalah penelitian kuantitatif. Jenis penelitian ini menggunakan tipe kuantitatif komparatif. Menurut Sugiono (2012:36) metode penelitian kuantitatif komparatif adalah penelitian komparatif suatu penelitian yang bersifat membandingkan

\section{B. Jenis dan Sumber Data}

Dalam penelitian yang dilakukan menggunakan jenis data yaitu data kuantitatif, dimana penulis melakukan pengumpulkan data yang berupa angka, atau data berupa kata-kata atau kalimat yag dikonversikan menjadi data yang berbentuk angka. Sumber data yang dipakai dalam penelitian ini adalah data primer dimana data yang dikumpulkan berupa dokumentasi proses produksi, laporan produksi, struktur organisasi dan informasi biaya-biaya dalam memproduksi produk jadi yang siap dijual. Menurut Sugiyono (2012:308) data primer merupakan sumber data penelitian yang diperoleh langsung dari sumber asli (tidak melalui perantara). Sumber data yang digunakan dalam penelitian ini berupa data primer.

\section{Teknik Pengumpulan Data}

Dalam penelitian ini mengunakan teknik pengumpulan data yang dilakukan adalah :

a. Observasi

Observasi dilakukan untuk mengumpulkan data yang diperlukan dengan cara mengamati langsung ke tempat objek penelitian yang akan diteliti. Dalam observasi peneliti melihat secara 
langsung keadaan lingkungan produksi, pengolahan bahan baku, bahan penolong yang digunakan, produktifitas tenaga kerja, dan peralatan dan mesin yang digunakan dalam proses produksi.

b. Wawancara

Wawancara yaitu teknik yang dilakukan dengan komunikasi secara langsung yang dilakukan dengan lisan dalam bentuk tanya jawab yang berhubungan dengan objek yang diteliti untuk memperoleh informasi secara langsung mengenai data yang diperoleh.

c. Dokumentasi

Teknik dokumentasi ialah teknik penulis melihat laporan data produksi produk dan foto dokumentasi foto proses produksi.

\section{Metode Analisis}

Penelitian ini menggunakan metode deskriptif, menurut Ulum and Juanda (2014 :78) metode deskriptif bertujuan menggambarkan sifat suatu yang tengah berlangsung pada saat riset dilakukan dan memeriksa sebab-sebab dari suatu gejala tertentu. Penelitian ini dilakukan dengan cara mengumpulkan, menghitung, membandingkan dan menganalisa data dan informasi yang telah diperoleh untuk mengambil suatu kesimpulan manfaat apa saja yang dapat diperoleh oleh perusahaan apabila menghitung HPP dengan menggunakan metode full costing ataupun variable costing dalam penentuan harga jual suatu produk sehingga dapat memberikan gambaran mengenai suatu keadaan tersebut

\section{HASIL DAN PEMBAHASAN}

\section{A. Hasil Penelitian}

Penentuan HPP yang dilakukan UD. Mutiara Furnitur masih sederhana dan belum merinci seluruh biaya yang di keluarkan dalam proses produksi. Biaya-biaya yang diakui hanya biaya bahan baku, bahan penolong dan biaya tenaga kerja saja. UKM ini tidak menghitung biaya overhead pabrik secara keseluruhan seperti biaya listrik, biaya telepon, bahan bakar minyak, komisi supir, pemeliharaan kendaraan dan penyusutan yang tidak diakui oleh pemilik UKM ketika menghitung HPP. Oleh karena itu peneliti membahas biaya-biaya apa saja yang diakui oleh UKM UD. Mutiara Furnitur. 
Pertama, biaya bahan baku Menurut Siregar (2014:317) adalah bahan-bahan yang menjadi bagian produk jadi dan dapat diidentifikasi ke produk jadi. Perusahaan menghitung biaya bahan baku yang digunakan dengan cara mengukur seberapa banyak bahan baku yang dihabiskan untuk memproduksi satu set sofa minimalis 211. Berikut adalah pemakaian biaya bahan baku dapat dilihat pada Tabel.1 yaitu :

\section{Tabel 1}

Biaya Bahan Baku Tahun 2018

\begin{tabular}{|l|l|}
\hline \multicolumn{1}{|c|}{ Keterangan } & \multicolumn{2}{c|}{ Jumlah } \\
\hline Kayu papan & $\mathrm{Rp} 61.600 .000$ \\
\hline Kayu balok & $\mathrm{Rp} 12.320 .000$ \\
\hline Busa & $\mathrm{Rp} \mathrm{123.200.000}$ \\
\hline Dakron & $\mathrm{Rp} 69.300 .000$ \\
\hline Kulit kain & $\mathrm{Rp} \mathrm{172.480.000}$ \\
\hline Kaki sofa & $\mathrm{Rp} \mathrm{33.264.000}$ \\
\hline $\begin{array}{l}\text { Total biaya bahan } \\
\text { baku }\end{array}$ & $\mathrm{Rp} \mathrm{472.164.000}$ \\
\hline
\end{tabular}

Sumber : Data diolah 2019

Kedua, biaya tenaga kerja menurut Supriyono (2013:20) adalah semua balas jasa yang akan diberikan perusahaan kepada semua karyawan. UD. Mutiara Furnitur menghitung biaya tenaga kerja langsung dan mandor berdasarkan unit yang dihasilkan. Menurut UD. Mutiara Furnitur upah mandor digabung penggolongannya dengan biaya tenaga kerja langsung. UD. Mutiara Furnitur mempunyai 6 orang karyawan yang dibagi menjadi 4 bagian yaitu bagian pemotongan kayu 1 orang, penjahitan 1 orang, proses perakitan pemasangan serta finishing 3 orang dan mandor 1 orang. Upah yang diberikan kepada masing-masing karyawan sama jumlahnya sebesar Rp 140.000/set. Jumlah total produksi pada tahun 2018 sebanyak 308 set sofa. Berdasarkan biayabiaya tenaga kerja yang telah ditentukan. Berikut adalah perhitungan biaya tenaga kerja pada UD. Mutiara Furnitur dapat dilihat pada Tabel.2 sebagai berikut :

\section{Tabel 2}

\section{Biaya Tenaga Kerja Tahun 2018}

\begin{tabular}{|l|c|}
\hline \multicolumn{1}{|c|}{ Keterangan } & \multicolumn{2}{|c|}{ Jumlah } \\
\hline Upah mandor & $\mathrm{Rp} 43.120 .000$ \\
\hline Upah tenaga kerja & $\mathrm{Rp} \mathrm{215.600.000}$ \\
\hline
\end{tabular}




\begin{tabular}{|l|l|} 
langsung & \\
\hline $\begin{array}{l}\text { Total biaya tenaga } \\
\text { kerja }\end{array}$ & $\operatorname{Rp} 258.720 .000$ \\
\hline \multicolumn{2}{|l|}{ Sumber : Data diolah 2019 }
\end{tabular}

Ketiga, perhitungan biaya overhead pabrik menurut Dunia dan Abdullah (2012:23) adalah semua biaya untuk memproduksi suatu produk selain dari bahan langsung dan tenaga kerja langsung. Perhitungan HPP UKM diketahui tidak semua biaya overhead pabrik diakui dalam perhitungannya. Sedangkan biaya overhead pabrik yang diakui oleh UD. Mutiara Furnitur pada saat menghitung HPP adalah biaya penolong. Berikut adalah rinciannya biaya penolong pada perusahaan, dapat dilihat pada Tabel. 3 sebagai berikut :

\section{Tabel 3}

\section{Biaya Penolong Tahun 2018}

\begin{tabular}{|l|lr|}
\hline \multicolumn{1}{|c|}{ Keterangan } & \multicolumn{2}{|c|}{ Jumlah } \\
\hline Kain biasa & $\mathrm{Rp}$ & 4.620 .000 \\
\hline Karet & $\mathrm{Rp}$ & 21.560 .000 \\
\hline Paku 1" \& 2" & $\mathrm{Rp}$ & 5.544 .000 \\
\hline Isi stapless & $\mathrm{Rp}$ & 9.240 .000 \\
\hline Lem busa & $\mathrm{Rp}$ & 12.936 .000 \\
\hline Lesriting bantal & $\mathrm{Rp}$ & 2.464 .000 \\
\hline Nilon & $\mathrm{Rp}$ & 1.848 .000 \\
\hline Plastik & $\mathrm{Rp}$ & 6.468 .000 \\
\hline $\begin{array}{c}\text { Total biaya } \\
\text { penolong }\end{array}$ & $\mathrm{Rp}$ & 64.680 .000 \\
\hline
\end{tabular}

Sumber : Data diolah 2019

\section{Perhitungan HPP dengan Metode Perusahaan}

Perhitungan HPP pada UD. Mutiara Furnitur dilakukan sebagai dasar dalam menentukan harga jual produk. Namun perhitungan HPP yang ditetapkan oleh UKM saat ini masih kurang efektif. Penentuan HPP yang dilakukan UKM masih sangat minim dan belum terperinci. Biayabiaya produksi yang diakui UKM seperti biaya bahan baku, biaya bahan penolong dan biaya tenaga kerja. UKM ini menjumlahkan biaya penolong dengan biaya bahan baku. Sedangkan upah mandor ditambah upah tenaga kerja langsung. UKM tidak menghitung biaya overhead pabrik secara 
lengkap dan terperinci. Perhitungan HPP HPP yang dihasilkan UKM sebesar Rp 2.583.000 per unit. Sedangkan total HPP pada tahun 2018 sofa sebesar Rp 795.564.000 dengan jumlah produksinya 308 set. Berdasarkan biaya-biaya yang ditentukan UKM dalam menentukan HPP, maka dapat dilihat perhitungan metode UKM pada Tabel 4 sebagai berikut :

\section{Tabel 4}

\section{Perhitungan HPP dengan Metode Perusahaan}

\begin{tabular}{|l|rr|}
\hline \multicolumn{1}{|c|}{ Keterangan } & \multicolumn{2}{c|}{ Total biaya } \\
\hline Biaya bahan baku & Rp & 536.844 .000 \\
\hline Biaya tenaga kerja & Rp & 258.720 .000 \\
\hline Biaya overhead pabrik & & - \\
\hline HPP & Rp & 795.564 .000 \\
\hline Jumlah produksi/tahun & & 308 Set \\
\hline HPP per unit & Rp & 2.583 .000 \\
\hline
\end{tabular}

Sumber : Data diolah 2019

\section{a) Perhitungan HPP dengan Metode Full costing}

Metode full costing menggunakan konsep harga pokok penuh yaitu dengan memasukan seluruh biaya poduksi, sehingga dapat menjamin keakuratan informasi yang tersaji dalam laporan HPP. Metode ini digunakan karena metode full costing sudah sesuai dengan prinsip akuntansi yang berlaku umum, sehingga dapat menjamin keakuratan informasi yang tersaji dalam laporan HPP. Biaya-biaya yang diakui dalam perhitungan HPP menggunakan metode full costing yaitu biaya bahan baku yang dikeluarkan perusahaan pada tahun 2018 sebesar Rp 472.164.000. Biaya tenaga kerja langsung yang dikeluarkan sebesar Rp 215.600.000. Biaya overhead pabrik yang dihitung menggunakan metode full costing dibagi menjadi biaya overhead pabrik variabel dan tetap. Biaya overhead pabrik variabel terdiri dari biaya listrik Rp 1.385.112, biaya bahan bakar minyak sebesar Rp 3.744.000, biaya telepon sebesar Rp 1.800.000. biaya komisi supir sebesar Rp 3.850.000, biaya pemeliharaan kendaraan sebesar Rp 1.200.000, biaya upah mandor sebesar Rp 43.120.000, biaya penolong sebesar Rp 72.072.000 sehingga jumlah biaya overhead pabrik variable sebesar Rp 127.171.112. Biaya overhead pabrik tetap terdiri dari biaya listrik tetap sebesar Rp 1.549.448, dan total biaya penyusutan sebesar Rp 27.820.938. Berikut adalah tabel rincian biaya penyusutan pada Tabel 5 berikut ini : 
Analisis Perhitungan Harga Pokok Produksi Berdasarkan Metode Full Costing dan Variable Costing Sebagai Dasar Dalam Menentukan Harga Jual Pada UKM. UD. Mutiara Furnitur Balikpapan, (Fauziah Yuspyani, Adi Prihanisetyo)

\section{Tabel 5}

\section{Perhitungan Biaya Penyusutan}

Aktiva Tetap

\begin{tabular}{|l|r|r|r|r|}
\hline \multicolumn{1}{|c|}{ Keterangan } & $\begin{array}{c}\text { Harga Beli } \\
\text { (Rp) }\end{array}$ & \multicolumn{1}{c|}{$\begin{array}{c}\text { Total } \\
\text { (Rp) }\end{array}$} & $\begin{array}{c}\text { Umur } \\
\text { Ekonomis } \\
\text { (Thn) }\end{array}$ & $\begin{array}{c}\text { Biaya } \\
\text { Penyusutan } \\
\text { (Rp/Thn) }\end{array}$ \\
\hline Bangunan & 250.000 .000 & 250.000 .000 & 20 & 12.500 .000 \\
\hline Mesin serkel & 1.700 .000 & 1.700 .000 & 4 & 425.000 \\
\hline Mobil Pick Up & 90.000 .000 & 90.000 .000 & 8 & 11.250 .000 \\
\hline Mesin Jahit (2) & 7.952 .000 & 15.904 .000 & 8 & 1.988 .000 \\
\hline Kompresor & 2.100 .000 & 2.100 .000 & 8 & 262.500 \\
\hline Staples Angin (3) & 320.000 & 960.000 & 4 & 240.000 \\
\hline Mesin Bor Kayu & 339.500 & 339.500 & 8 & 42.438 \\
\hline Mesin Genset & 8.000 .000 & 8.000 .000 & 8 & 1.000 .000 \\
\hline Peralatan & 452.000 & 452.000 & 4 & 113.000 \\
\hline \multicolumn{5}{|r|}{ Total Penyusutan } \\
\hline
\end{tabular}

Berdasarkan pada Tabel 5.5 di atas dapat diketahui bahwa perhitungan biaya penyusutan per tahun pada tahun 2018 sebesar Rp 27.820.938. Berdasarkan HPP menggunakan metode full costing dapat dilihat pada Tabel 6 yaitu:

Tabel. 6

Perhitungan HPP dengan Metode Full Costing

\begin{tabular}{|c|c|}
\hline Keterangan & Total biaya \\
\hline Biaya bahan baku & Rp 472.164.000 \\
\hline $\begin{array}{l}\text { Biaya tenaga kerja } \\
\text { langsung }\end{array}$ & Rp 215.600.000 \\
\hline $\begin{array}{l}\text { Biaya overhead pabrik } \\
\text { variabel }\end{array}$ & Rp 127.171.112 \\
\hline $\begin{array}{l}\text { Biaya overhead pabrik } \\
\text { tetap }\end{array}$ & Rp $\quad 29.370 .385$ \\
\hline Total baya produksi & Rp 844.305.498 \\
\hline Jumlah produksi/tahun & 308 Set \\
\hline HPP per unit & Rp $\quad 2.741 .252$ \\
\hline
\end{tabular}

Sumber : Data diolah 2019 
Dari hasil perhitungan dengan menggunakan metode full costing dapat dilihat jauh perbedaannya angka nominalnya dengan perhitungan perusahaan maupun perhitungan variable costing dan perhitungan perusahaan. Bisa dilihat dari hasil perhitungan dengan metode full costing untuk produk sofa minimalis 211 sebesar Rp 844.305.498 dengan jumlah produksi tahun 2018 sejumlah 308 set dan HPP per unit sebesar Rp 2.741.252.

\section{b) Perhitungan HPP dengan Metode Variable costing}

Variable Costing adalah metode penentuan HPP yang hanya memperhitungkan biaya produksi biaya produksi yang berperilaku variabel ke dalam HPP, yang terdiri dari biaya bahan baku, biaya tenaga kerja langsung, dan biaya overhead pabrik variabel. Metode ini cocok untuk kebutuhan jangka pendek perusahaan dan informasi perhitungan HPPnya lebih ditujukan untuk memenuhi kebutuhan internal manajemen perusahaan. Metode variable costing juga tidak sesuai dengan prinsip akuntansi yang berlaku umum. Biaya-biaya produksi yang diakui dalam perhitungan HPP menggunakan metode variable costing seperti biaya bahan baku sebesar Rp 472.164.000, biaya tenaga kerja langsung sebesar Rp 215.600.000 dan biaya overhead pabrik variabel sebesar Rp 127.171.112 yang terdiri dari biaya biaya listrik Rp 1.385.112, biaya bahan bakar minyak sebesar Rp 3.744.000, biaya telepon sebesar Rp 1.800.000, biaya komisi supir sebesar Rp 3.850.000, biaya pemeliharaan kendaraan sebesar Rp 1.200.000, biaya upah mandor / pengawas sebesar Rp 43.120.000, biaya penolong sebesar Rp 72.072.000. Berdasarkan biayabiaya di atas, maka dapat dilihat perhitungan HPP menggunakan metode variable costing pada Tabel 7 berikut ini :

Tabel 7

Perhitungan HPP dengan Metode Variable Costing

\begin{tabular}{|l|r|}
\hline \multicolumn{1}{|c|}{ Keterangan } & \multicolumn{1}{c|}{ Total biaya } \\
\hline Biaya bahan baku & $\mathrm{Rp} \mathrm{472.164.000}$ \\
\hline $\begin{array}{l}\text { Biaya tenaga kerja } \\
\text { langsung }\end{array}$ & $\mathrm{Rp} \mathrm{215.600.000}$ \\
\hline $\begin{array}{l}\text { Biaya } \text { overhead pabrik } \\
\text { variabel }\end{array}$ & $\mathrm{Rp} \mathrm{127.171.112}$ \\
\hline Total baya produksi & $\mathrm{Rp} \mathrm{814.935.112}$ \\
\hline Jumlah produksi/tahun & 308 Set \\
\hline HPP per unit & $\mathrm{Rp} 2.645 .893$ \\
\hline
\end{tabular}


Sumber : Data diolah 2019

Dari hasil perhitungan dengan menggunakan metode variable costing dapat dilihat jauh perbedaannya angka nominalnya dengan perhitungan perusahaan maupun perhitungan full costing dan perhitungan perusahaan. Bisa dilihat dari hasil perhitungan dengan metode variable costing untuk produk sofa minimalis 211 sebesar Rp 814.935.112 dengan jumlah produksi tahun 2018 sejumlah 308 set dan HPP per unit sebesar Rp 2.465.893.

\section{c) Perbandingan HPP dengan Metode Perusahaan, Full Costing dan Variable Costing Serta Pengaruhnya Terhadap Harga Jual Produk}

Perhitungan HPP pada pembahasan sebelumnya dapat dijadikan dasar untuk melakukan analisis perbandingan antara metode perusahaan dengan metode full costing dan variable costing dalam menentukan harga jual. Perbandingan dari ketiga metode HPP tersebut mempengaruhi terhadap perhitungan harga jual produk. Menurut Sujarweni (2015:75) Metode penentuan harga jual berdasarkan biaya dalam bentuk yang paling sederhana yaitu menggunakan Cost plus pricing method yang dapat digunakan dengan rumus: Harga jual = Biaya total + Margin

Margin yang diinginkan oleh perusahaan sebesar 35\% dari HPP perunit, sehingga jumlah harga jual produk yang ditentukan oleh perusahaan sebesar $\operatorname{Rp} 3.487 .050(\operatorname{Rp} 2.583 .000+(35 \%$ $\mathrm{x} \quad \mathrm{Rp}$ 2.583.000) nilai tersebut dibulatkan oleh perusahaan sebesar Rp 3.500.000. Perbandingan dari ketiga metode tersebut dapat dilihat pada Tabel 8 berikut ini :

\section{Tabel 8}

\section{Perbandingan HPP dan Harga Jual}

\section{Cost plus pricing}

\begin{tabular}{|c|c|c|c|c|c|}
\hline Keterangan & $\begin{array}{c}\text { Metode } \\
\text { Perusahaan } \\
\text { (Rp) }\end{array}$ & $\begin{array}{l}\text { Metode } \\
\text { Full Costing } \\
\text { (Rp) }\end{array}$ & $\begin{array}{l}\text { Metode } \\
\text { Variabel } \\
\text { Costing } \\
\text { (Rp) }\end{array}$ & $\begin{array}{c}\text { Perbandingan } \\
\text { Full costing } \\
\text { (Rp) }\end{array}$ & $\begin{array}{c}\text { Perbandingan } \\
\text { Variable } \\
\text { costing (Rp) }\end{array}$ \\
\hline Biaya Bahan Baku & 536.844 .000 & 472.164 .000 & 472.164 .000 & 64.680 .000 & 64.680 .000 \\
\hline Biaya Tenaga Keria & 258.720 .000 & 215.600 .000 & 215.600 .000 & 43.120 .000 & 43.120 .000 \\
\hline \multicolumn{6}{|c|}{ Biaya Overhead Pabrik: } \\
\hline BOP Variabel & - & 127.171 .112 & 127.171 .112 & & \\
\hline BOP Tetap & - & 29.370 .385 & - & & \\
\hline $\begin{array}{l}\text { Total Biaya } \\
\text { Overhead Pabrik }\end{array}$ & & 156.541 .498 & 127.171 .112 & $(156.541 .498)$ & $(127.171 .112)$ \\
\hline Total Biaya Produksi & 795.564 .000 & 844.305 .498 & 814.935 .112 & $(48.741 .498)$ & $(19.371 .112)$ \\
\hline $\begin{array}{l}\text { Jumlah Produk Yang } \\
\text { Dihasilkan }\end{array}$ & $308 \mathrm{Set}$ & $308 \mathrm{Set}$ & 308 Set & & \\
\hline $\begin{array}{l}\text { Harga Pokok } \\
\text { Produksi Per Unit } \\
\text { UD. Mutiara Fumitur }\end{array}$ & 2.583 .000 & 2.741 .252 & 2.645 .893 & $(158.252)$ & $(62.893)$ \\
\hline $\begin{array}{l}\text { Harga jual sofa } \\
\text { (HPP }+(35 \% \text { x HPP })\end{array}$ & 3.500 .000 & 3.700 .690 & 3.571 .956 & $(200.690)$ & (71.956) \\
\hline
\end{tabular}


1. Berdasarkan Tabel 8 di atas dapat dilihat bahwa dari perhitungan menggunakan metode perusahaan, metode full costing dan metode variable costing terdapat perbedaan jumlah harga pokok dan harga jual produksi sofa. Perhitungan menggunakan metode perusahaan memberikan hasil yang lebih rendah dibandingkan dengan menggunakan metode full costing dan metode variable costing. Selisih dari ketiga metode HPP per unit yaitu antara HPP full costing dengan HPP metode perusahaan sebesar Rp 158.252 per unit $(\mathrm{Rp} 2.741 .252$ - Rp 2.583.000) dan antara HPP variable costing dengan HPP metode perusahaan sebesar Rp 62.893 per unit (Rp 2.645.893 - Rp 2.583.000). Selisih tersebut terjadi karena perbedaan nilai pada biaya overhead pabrik saat melakukan perhitungan HPP. Harga jual yang dihasilkan dari ketiga metode tersebut menunjukan hasil yang berbeda. Perusahaan menentukan harga jual dengan sebesar Rp 3.500.000 per unit harga jual tersebut lebih rendah dibandingkan harga jual full costing dan variable costing, sedangkan penentuan HPP menggunakan metode full costing sebesar Rp 2.741.252 menghasilkan harga jual menggunakan metode cost plus pricing sebesar Rp 3.700.690 per unit dari margin perusahaan sebesar 35\%. Penentuan HPP menggunakan metode variable costing sebesar Rp 2.645 .893 per unit dan menghasilkan harga jual menggunakan metode cost plus pricing sebesar Rp 3.571.956 per unit dari margin perusahaan sebesar 35\%. HPP per unit sebesar Rp 2.741.252. Total biaya produksi pertahun yang dihasilkan metode variable costing pada tahun 2018 sebesar Rp 814.935.112, sedangkan HPP per unit sebesar Rp 2.645.893. Jumlah produk sofa yang dihasilkan pada tahun 2018 sebanyak 308 set.

2. Berdasarkan perbandingan perhitungan HPP menggunakan metode perusahaan, metode full costing dan variable costing yang dihasilkan memiliki perbedaan. Perhitungan yang dihasilkan menggunakan metode perusahaan lebih rendah daripada metode full costing dan variable costing. Laba yang diperoleh UKM saat ini sebesar Rp 917.000, namun laba tersebut bukanlah laba bersih yang seharusnya diperoleh UKM karena terdapat biaya-biaya yang belum diakui oleh UKM. 


\section{KESIMPULAN DAN SARAN}

\section{A. Kesimpulan}

Berdasarkan hasil analisis dari pembahasan yang telah dilakukan pada bab sebelumnya maka dapat ditarik beberapa kesimpuan sebagai berikut :

1. Berdasarkan hasil perhitungan Perhitungan HPP yang dilakukan oleh UKM UD. Mutiara Furnitur dalam perhitungan HPP menggunakan metode sederhana. HPP per unit sofa sebesar Rp 2.583.000.

2. Berdasarkan hasil perhitungan biaya produksi yang dilakukan UKM UD. Mutiara Furnitur pada tahun 2018 sebesar Rp 795.564.000 sedangkan HPP per unit sofa sebesar Rp 2.583.000. Total biaya produksi pertahun yang dihasilkan metode full costing pada tahun 2018 sebesar Rp 844.305.498, sedangkan HPP per unit sebesar Rp 2.741.252. Total biaya produksi pertahun yang dihasilkan metode variable costing pada tahun 2018 sebesar Rp 814.935.112, sedangkan HPP per unit sebesar Rp 2.645.893. Jumlah produk sofa yang dihasilkan pada tahun 2018 sebanyak 308 set.

3. Berdasarkan perbandingan perhitungan HPP menggunakan metode perusahaan, metode full costing dan variable costing yang dihasilkan memiliki perbedaan. Perhitungan yang dihasilkan menggunakan metode perusahaan lebih rendah daripada metode full costing dan variable costing. Laba yang diperoleh UKM saat ini sebesar Rp 917.000, namun laba tersebut bukanlah laba bersih yang seharusnya diperoleh UKM karena terdapat biaya-biaya yang belum diakui oleh UKM.

\section{B. Saran}

Berdasarkan kesimpulan yang telah dipaparkan maka dapat dikemukakan saran yang mungkin berguna bagi perusahaan dalam mengembangkan usahanya sebagai berikut :

1. Sebaiknya UKM mencatat inventaris / peralatan yang digunakan untuk dapat dilakukan perhitungan penyusutan.

2. Sebaiknya UKM menggunakan perhitungan dengan metode full costing karena metode ini merinci seluruh biaya yang dikeluarkan pada saat kegiatan produksi baik yang bersifat variabel maupun tetap.

3. Sebaiknya pemilik usaha lebih tertib dan disiplin dalam mengarsip bukti-bukti transaksi seperti 
nota-nota biaya produksi.

4. Jika UKM menggunakan metode full costing maka bisa menggunakan harga jual sebesar Rp 3.700.690.

5. Bagi peneliti selanjutnya dapat membandingkan antara perhitungan HPP dengan penentuan biaya dalam hubungannya dengan aktivitas bisnis dalam organisasi yang dapat diterapkan untuk menghitung biaya produksi.

\section{DAFTAR PUSTAKA}

Ahmad, Kamaruddin. 2013. Akuntansi Manajemen: Dasar-Dasar Konsep Biaya Dan Pengambil Keputusan. Jakarta: Raja Grafindo Persada.

Ardianne, Fourqoni Noordiana. 2013. Analisis Penentuan Biaya Produksi Berdasarkan Metode Full Costing Dalam Pembuatan Lemari Dan Sofa Pada Ainun Jati Meubel. Universitas Jember.

Astuti, Partiwi Dwi. 2012. Akuntansi Keuangan Dasar 1. Penerbit CAPS. Yogyakarta.

Basu, Swastha dan Irawan, 2007, Manajemen Pemasaran Modern, Liberty Offset, Yogyakarta.

Baridwan, Zaki, 2004, Intermediate Accounting, Edisi Kedelapan, Yogyakarta:BPFE.BBPFE.

Bhayangkara, Zifi. 2016. Perhitungan Harga Pokok Pesanan Untuk Menetapkan Harga Jual (Studi Kasus Pada Usaha Riau Alumunium), Jurnal Akuntansi Keuangan dan Bisnis Vol.9, Politeknik Caltex Riau.

Carter, William K dan Usry, Milton F. 2014. Akuntansi Biaya. Diterjemahkan oleh Krista. Buku 1. Edisi Keempat Belas. Jakarta: Salemba Empat.

Costing dalam Perhitungan HPP pada Usaha Moulding Karya Mukti Samarinda. E-Journal Ilmu Administrasi Bisnis Vol. 2 No. 2.

Dunia, Firdaus Ahmad dan Wasilah Abdullah. 2012. Akuntansi Biaya. Jakarta:Salemba Empat

Garrison, Ray H, Norren, Brewer. 2013. Akuntansi Manajerial. Jakarta: Salemba Empat.

Hansen, Don R \& Mowen, Marryanne M. 2013. Manajemen Biaya, Edisi Bahasa Indonesia, Buku Dua, Edisi Pertama. Jakarta. Salemba Empat.

Harrison, Walter. T. Jr. et.al. 2012. Akuntansi Keuangan: International Financial Reporting Standars. Penerjemah Gina Gania. Jakarta: Erlangga.

Husein, Umar. 2013. Metode Penelitian untuk Skripsi dan Tesis. Jakarta: Rajawali

Harini. 2008. Penetapan Harga ,Makro Ekonomi Pengantar, PT Gramedia 
Ikatan Akuntan Indonesia (IAI). 2018. Standar Akuntansi Keuangan Entitas MIkro,Kecil, Dan Menengah ( SAK UMKM). Jakarta : Dewan Standar Akuntansi Keuangan Ikatan Akuntan Indonesia.

Mulyadi. 2001. Akuntansi Manajemen, Edisi Ketiga. Jakarta: Salemba Empat.

Mulyadi, 2014, Akuntansi Biaya, Edisi kelima, UPP STIM YKPN, Yogyakarta.

Musdalifah, dkk. 2014. Penerapan Metode Variable Costing Dalam Penentuan Harga Jual Pada PT. Cahaya Murni Raya Indonesia.Jurnal EMBA, Vol. 2. No. 3. Hal. 096-102.

Rifqi, Anshar Hawari Mochammad. 2014. Analisis Full Costing dan Variable

Raiborn, Cecily A, and Kinney, Michael R. dalam Edward Tanujaya. 2011. Akuntansi Biaya Dasar dan Perkembangan. Jakarta: Salemba Empat.

Ramdani ,Muhammad Reza. 2017. Penetapan Harga Jual Produk Dengan Pendekatan Full Costing Dan Variable Costing Pada UMKM Gunung Jaya Makassar. Universitas Muslim Indonesia.

Rudianto. 2012. Pengantar Akuntansi Konsep Dan Teknik Penyusunan Laporan Keuangan. Jakarta : Penerbit Erlangga.

Sari, Vanda Novita. 2016. Analisis Penerapan Metode Variable Costing Dalam Menentukan HPP Pada UKM Di Banda Aceh. Jurnal Ilmiah Mahasiswa Ekonomi Akuntansi Vol. 1, No.2, Universitas Syiah Kuala.

Samsul, Niniek H. 2013. Perbandingan HPP Full Costing dan Variable Costing Untuk Harga Jual CV. Pyramid.

Sylvia, Rika. 2018. Analisis Perhitungan HPP Dengan Menggunakan Metode Full Costing Dan Variable Costing Pada Tahu Mama Kokom Kotabaru.

Siregar, Baldric, dkk. 2013. Akuntansi Manajemen. Jakarta: Salemba Empat.

Sugiyono. 2012. Metode Penelitian Kuantitatif Kualitatif dan R\&D. Bandung:Alfabeta.

Sujarweni, V. Wiratna. 2015. Akuntansi Biaya-Teori dan Penerapannya. Yogyakarta : Pustaka Baru Press.

Supriyono, R.A. 2013. Akuntansi Biaya. Edisi 2. Yogyakarta: BPFE.

Undang-Undang No. 20 Tahun 2008 tentang Usaha Mikro, Kecil, dan Menengah.

Yuniari, Ni Kadek. 2017. Analisis Ketepatan Perhitungan HPP Berdasarkan Metode Full Costing Sebagai Dasar Dalam Menentukan Harga Jual Ukiran Sanggah (Pelinggih) Pada Usaha Sari Uma Dukuh Sidemen.

Sumber Internet : 
2018. FINANCIALKU AND NEWS. https://www.financialku.com/tariff-dasar-listrik-2018/. diakses pada 20 Mei 2019. (20.00)

2019. KEMENTRIAN KEUANGAN DIREKTORAT JENDERAL PAJAK.

https://www.pajak.go.id/index.php/id/

penyusutan-dan-amortisasi. diakses pada 1 Desember 2019. (14.00)

2019. PT. PLN (PERSERO). https://www.pln.co.id/pelanggan/layanan-online. diakses pada 1 Desember 2019. (15.00)

https://www.ukmindonesia.id/bacaartikel/ 66. diakses pada 17 April 2019. (19.00) 